\title{
KARAKTERISTIK KUALITAS AIR DAN ESTIMASI RESIKO EKOBIOLOGI HERBISIDA DI PERAIRAN RAWA BANJIRAN LUBUK LAMPAM, SUMATERA SELATAN \\ (Water Quality Characteristics and Estimation of Ecobiological Risk of Herbicide in Lubuk Lampam Floodplain, South Sumatera)
}

\author{
Dade Jubaedah, M. Mukhlis Kamal", Ismudi Muchsin dan Sigid Hariyadi \\ Program Studi Pengelolaan Sumberdaya Perairan, Departemen Manajemen Sumber Daya Perairan, \\ Fakultas Perikanan dan Ilmu Kelautan, Institut Pertanian Bogor (IPB), \\ Kampus Dramaga, Bogor 16680. \\ *Penulis korespondensi. No Tel: 0251-8622932 / 0251-8622907. \\ Email:m_mukhliskamal@yahoo.com.
}

Diterima: 5 Desember 2014

Disetujui: 13 Januari 2015

\begin{abstract}
Abstrak
Perairan rawa banjiran Lubuk Lampam (RBLL) merupakan ekosistem khas yang mempunyai arti penting terutama secara ekologi sebagai habitat ikan khas rawa banjiran. Penelitian ini bertujuan untuk mengetahui karakteristik kualitas air di RBLL terkait dengan perubahan muka air dan adanya masukan bahan antropogenik terutama dari kegiatan perkebunan kelapa sawit yang berada di dalam dan sekitar area RBLL. Hasil penelitian ini menunjukkan bahwa curah hujan merupakan faktor utama yang mempengaruhi perubahan muka air di RBLL. Fluktuasi muka air yang tidak ekstrim sebagai akibat dari curah hujan yang relatif merata sepanjang tahun menyebabkan karakteristik kualitas air antar periode musim menjadi cenderung sama. Secara umum, karakteristik kualitas air RBLL dicirikan dengan $\mathrm{pH}$ cenderung asam, kandungan oksigen rendah, kekeruhan tinggi serta konsentrasi total nitrogen dan total fosfor yang tinggi. Bahan antropogenik berupa herbisida dari jenis paraquat dan glyfosat ditemukan dalam konsentrasi relatif kecil (rataan 0,004 $\mathrm{mg} / \mathrm{L}$ dan $0,003 \mathrm{mg} / \mathrm{L}$ ), sehingga berdasarkan nilai resiko (Risk Quotient, RQ) kedua jenis herbisida ini memiliki resiko ekobiologi rendah $(<0,01)$ sampai dengan sedang $(0,01<\mathrm{RQ} \leq 0,1)$.
\end{abstract}

Kata kunci: ekosistem rawa, herbisida, kualitas air, rawa banjiran, resiko ekobologi.

\begin{abstract}
Lubuk Lampam floodplain is one of unique ecosystems that has important ecologycal value as floodplain fishes habitat. The objective of this study was to identify the water quality characteristics in Lubuk Lampam related to the water level fluctuation and anthropogenic substance especially from oil palm plantation activities that was develop in Lubuk Lampam area. The results study showed that water level fluctuation affected mainly by local rainfall. The pattern of local rainfall was not significantly different seasonally causing water quality characteristic simillar year-around. The general water quality characterisctis of Lubuk Lampam floodplain were acid waters, low dissolved oxygen, turbid, and high total nitrogen dan total phosphorus concentrations. Anthropogenic substance, i.e. from herbiside paraquat and glyphosate, found in study area with low concentration (mean values $0.004 \mathrm{mg} / \mathrm{L}$ and $0.003 \mathrm{mg} / \mathrm{L}$, respectively). Hence, based on Risk Quotient (RQ) the ecobiological risk of two kinds of herbicides were low $(<0.01)$ and moderate $(0.01<R Q \leq 0.1)$.
\end{abstract}

Keywords: ecobiological risk, floodplain, floodplain ecosystem, herbicide, water quality.

\section{PENDAHULUAN}

Rawa banjiran mempunyai sistem ekologi termasuk karakteristik fisika-kimia yang khas terkait musim maupun habitat dan subhabitat yang ada di ekosistem ini. Sistem hidrologi di rawa banjiran menyebabkan adanya periode tergenang dan kering area rawa. Karakteristik ekologi maupun hidrologi rawa banjiran menjadi faktor kunci bagi biodiversitas maupun produktivitas ekosistem ini (Graham dan Harris, 2005). Rawa banjiran Lubuk Lampam (RBLL) merupakan ekosistem alami yang bernilai penting terutama sebagai habitat bagi beberapa jenis ikan khas rawa banjiran antara lain Channa striata, Helostoma temmincki, dan Osteochilus hasselti. Untuk kepentingan keberlanjutan spesies-spesies ikan rawa banjiran tersebut, pemerintah telah menetapkan beberapa kawasan di Lubuk Lampam sebagai reservat atau suaka perikanan antara lain suaka perikanan tipe lebung yaitu Suak Buayo dan lebung Proyek yang masing-masing luasnya 0,4 hektar dan $1.200 \mathrm{~m}^{2}$, serta suaka perikanan tipe sungai sepanjang $1,4 \mathrm{~km}$ dengan lebar sekitar 30 m (Asyari dkk., 2002).

Menurut Husnah (2008), tantangan yang dihadapi dalam menjaga keseimbangan ekosistem 
RBLL adalah perubahan tata guna lahan di area RBLL. Sejak sekitar tahun 2005, area RBLL telah dikembangkan melalui konversi dari lahan banjiran alami menjadi area pertanian dan perkebunan terutama perkebunan kelapa sawit. Hasil pengamatan Husnah (2008), pada bulan Mei 2008 di sepanjang sungai Lempuing dan rawa banjiran di sekitarnya telah didominasi perkebunan kelapa sawit. Perkembangan industri biomassa kelapa sawit dan biodiesel berkontribusi terhadap pencemaran perairan terutama disebabkan ekspansi lahan dan proses pengolahannya. Selain itu, dampak perubahan iklim terhadap perubahan curah hujan lokal menyebabkan perubahan fluktuasi muka air di RBLL.

Perubahan karakteristik limnologi terutama fluktuasi muka air, fisika-kimia air dan estimasi resiko ekobiologi sebagai akibat adanya perubahan tersebut menjadi tujuan utama kajian penelitian ini. Hasil kajian ini diharapkan dapat menjadi dasar dalam penentuan strategi pengelolaan sumberdaya perairan rawa banjiran yang tepat sehingga keberlanjutan ekosistem ini dapat terus terjaga.

\section{METODE PENELITIAN}

Penelitian dilakukan di rawa banjiran Lubuk Lampam (RBLL), Kabupaten Ogan Komering Ilir Propinsi Sumatera Selatan, Indonesia. Lubuk Lampam merupakan rawa banjiran dengan sungai utama Sungai Lempuing, salah satu anak sungai Komering. Pada tahun 2013, total area Lubuk Lampam sekitar 12.000 ha, terdiri atas lebak kumpai 927,3 ha, lebung 0,8 ha, hutan rawa 128,2 ha, sungai utama 19,5 ha dan perkebunan kelapa sawit 74,3 ha.

Stasiun pengambilan sampel terdiri atas 6 stasiun yang merupakan habitat dan subhabitat di RBLL serta 1 stasiun yang merupakan kanal perusahaan perkebunan kelapa sawit yang berada di area penelitian (Gambar 1). Pengukuran parameter kualitas air dan pengambilan sampel air dilakukan setiap bulan selama satu tahun (Desember 2012 sampai dengan November 2013). Ketinggian muka air diukur setiap minggu, sedangkan bahan antropogenik yaitu herbisida jenis paraquat dan glyfosat diukur hanya 2 kali yaitu pada periode muka air tertinggi dan periode muka air terendah). Rata-rata curah hujan diperoleh dari Badan Meteorologi, Klimatologi dan Geofisika (BMKG) stasiun Klimatologi Kelas I Kenten, Palembang. Pengukuran parameter kualitas air di lapangan (in situ), pengambilan, pengawetan, pengangkutan dan analisis sampel air dilakukan berdasarkan metode standar dari APHA (Anonim, 1998). Hubungan antara ketinggian muka air dan curah hujan dianalisis menggunakan analisis korelasi Spearman dengan taraf nyata $\mathrm{p}<0,05$.
Hasil pengukuran kedalaman atau muka air selama satu tahun dilakukan analisis klaster untuk memperoleh perbedaan periode penggenangan (Jubaedah dkk., 2014 ) (Gambar 2). Berdasarkan hasil analisis tersebut diperoleh 5 periode penggenangan, yaitu periode tergenang 1 (bulan Desember 2012, Januari 2013 dan Maret 2013), periode muka air tertinggi (Bulan Februari 2013), periode air mulai surut (bulan April 2013), periode air surut (bulan Mei 2013 sampai dengan Agustus 2013), periode tergenang 2 (bulan September 2013 sampai dengan November 2012). Meskipun dari hasil analisis klaster ini terlihat bahwa antar periode penggenangan menunjukkan perbedaan yang tidak signifikan (perbedaan similaritas $<10 \%$ ), yang membuktikan bahwa pada waktu pengamatan tidak terjadi pasang-surut yang ekstrim atau tidak terjadi perbedaan yang jelas antara musim kering dan musim banjir, namun, hasil analisis klaster ini digunakan dengan tujuan untuk memperoleh gambaran perubahan genangan di area RBLL.

Resiko bioekologis dihitung berdasarkan formula Risk Quotient (RQ) (Karras dkk., 2007, Karimi $d k k$. 2012). Formula RQ adalah sebagai berikut :

$$
\mathrm{RQ}=\sum_{i=1}^{n} \frac{C_{i}}{L C_{x i}}
$$

$\mathrm{C}_{\mathrm{i}}$ adalah konsentrasi senyawa $\mathrm{i}, \mathrm{n}$ adalah jumlah senyawa terdeteksi, dan $\mathrm{LC}_{\mathrm{xi}}$ adalah $\mathrm{LC}_{50}$. Klasifikasi kelas resiko dari nilai $\mathrm{RQ}$ adalah rendah $(<0,01)$, sedang $(0,01<R Q \leq 0,1)$, tinggi $(0,1<R Q \leq 1)$ dan sangat tinggi (RQ $>1)$ (Karras dkk. 2007, Karimi $d k k$. 2012).

\section{HASIL DAN PEMBAHASAN}

Berdasarkan hasil pengamatan diketahui bahwa fluktuasi muka air di setiap area RBLL dipengaruhi terutama oleh curah hujan lokal. Hal ini ditunjukkan dengan hubungan antara ketinggian muka air dan curah hujan lokal (Tabel 1).

Korelasi yang kuat terutama ditunjukkan di area Lebak Kumpai (stasiun 2 dan 6), Lebung Proyek (stasiun 4), dan segmen sungai baik hulu maupun hilir (stasiun 1 dan 7) menunjukkan bahwa curah. hujan lokal merupakan faktor utama yang mempengaruhi banjir di area ini. Korelasi yang lemah antara curah hujan dan ketinggian muka air di stasiun lebung Suak Buayo (stasiun 3) diduga disebabkan Suak Buayo merupakan lebung yang memiliki konektivitas sepanjang tahun dengan sungai serta kanal-kanal minor dari area perkebunan kelapa sawit. Korelasi yang lemah juga diperoleh di lokasi kanal utama (mayor) perkebunan kelapa sawit (stasiun 5), diduga disebabkan selain curah hujan, kenaikan muka air di area ini dipengaruhi oleh intensitas dan frekuensi pembuangan atau runoff dari kegiatan perkebunan. 


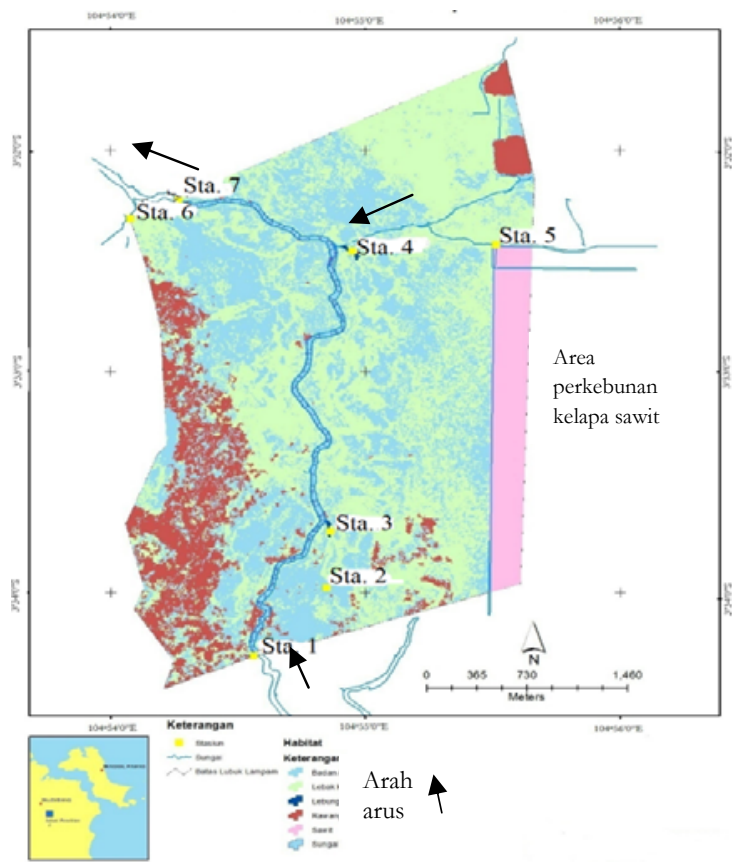

Keterangan stasiun (sta.) pengamatan :

Stasiun 1 : segmen sungai bagian hulu RBLL atau Kapak Hulu

Stasiun 2 : Lebak Kumpai 1

Stasiun 3 : Suak Buayo.

Stasiun 4 : Lebung Proyek

Stasiun 5 : kanal perkebunan kelapa sawit

Stasiun 6 : Lebak Kumpai 2

Stasiun 7 : segmen sungai bagian hilir RBLL

Gambar 1. Lokasi penelitian di area rawa banjiran Lubuk Lampam.

Tabel 1. Hubungan antara rata-rata curah hujan $(\mathrm{mm})$ dan ketinggian muka air pada masing-masing stasiun pengamatan.

\begin{tabular}{lcrrrrrrr}
\hline \multicolumn{1}{c}{ Waktu pengamatan } & $\begin{array}{c}\text { Curah hujan } \\
(\mathrm{mm})\end{array}$ & \multicolumn{7}{c}{ Ketinggian muka air (mm) } \\
\cline { 3 - 8 } & 319 & Sta. 1 & Sta. 2 & Sta. 3 & Sta. 4 & Sta. 5 & Sta. 6 & Sta. 7 \\
\hline Desember 2012 & 361 & 3,4 & 1,0 & 3,6 & 3,1 & 2,7 & 2,0 & 3,0 \\
Januari 2013 & 473 & 4,1 & 2,4 & 3,7 & 3,2 & 3,0 & 2,0 & 3,0 \\
Februari 2013 & 372 & 3,2 & 1,1 & 2,9 & 3,1 & 2,6 & 1,9 & 2,8 \\
Maret 2013 & 398 & 3,6 & 1,7 & 4,1 & 3,5 & 3,3 & 2,2 & 3,1 \\
April 2013 & 146 & 2,3 & 0,1 & 3,1 & 2,6 & 2,9 & 0,1 & 2,2 \\
Mei 2013 & 232 & 2,9 & 0,1 & 3,5 & 3,0 & 3,1 & 0,1 & 2,6 \\
Juni 2013 & 186 & 2,2 & 0,1 & 2,8 & 2,2 & 2,3 & 0,1 & 1,8 \\
Juli 2013 & 127 & 3,0 & 0,1 & 3,7 & 2,8 & 3,0 & 0,1 & 2,2 \\
Agustus 2013 & 302 & 2,4 & 0,8 & 3,0 & 2,5 & 2,5 & 1,1 & 2,0 \\
September 2013 & 136 & 2,5 & 0,6 & 3,1 & 2,7 & 2,1 & 0,9 & 2,1 \\
Oktober 2013 & 244 & 2,6 & 0,6 & 3,2 & 2,9 & 2,7 & 1,1 & 2,2 \\
November 2013 & & 0,80 & 0,91 & 0,48 & 0,79 & 0,36 & 0,91 & 0,83 \\
\hline Koefisien korelasi & & & & 3,9 & 4,0 & 2,9 & 2,1 \\
\hline
\end{tabular}

Keterangan : Stasiun pengamatan : Sta. 1 (Kapak Hulu), Sta. 2 (Lebak Kumpai 1), Sta. 3 (Suak Buayo), Sta. 4 (Lebung Proyek), Sta. 5 (kanal perkebunan kelapa sawit), Sta. 6 (Lebak Kumpai 2), dan Sta. 7 (segmen sungai bagian hilir RBLL).

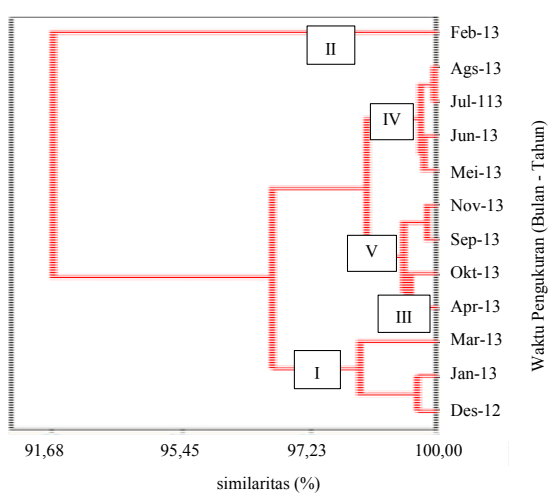

Gambar 2. Periode penggenangan di RBLL (I: periode penggenangan 1, II: periode muka air tertinggi, III: periode mulai surut, IV: periode surut, $\mathrm{V}$ : periode tergenang 2) (Jubaedah $d k k .2014^{\mathrm{a}}$ ).
Gambaran profil ketinggian muka air di area RBLL pada bulan Desember 2012, Februari 2013, Mei 2013, Juli 2013, Agustus 2013 dan November 2013 (Gambar 3), menunjukkan perubahan ketinggian muka air yang akan mempengaruhi luasan area yang tergenang di RBLL. Berdasarkan pengambilan gambar melalui citra satelit Worldview-2 (Gambar 4), terlihat perbedaan luas genangan pada saat muka air tertinggi (bulan Februari 2013) area tergenang sekitar 1.073,6 hektar, dan pada saat surut (bulan Juni 2013), area tergenang hanya sekitar 886,1 ha. Kondisi pada saat surut terendah (bulan Juli 2013) tidak bisa disajikan karena peta citra menunjukkan area tertutup awan.

Rerata kualitas air yang diperoleh berdasarkan periode penggenangan air disajikan pada Tabel 2 . Secara umum. karakteristik kualitas air di lokasi 

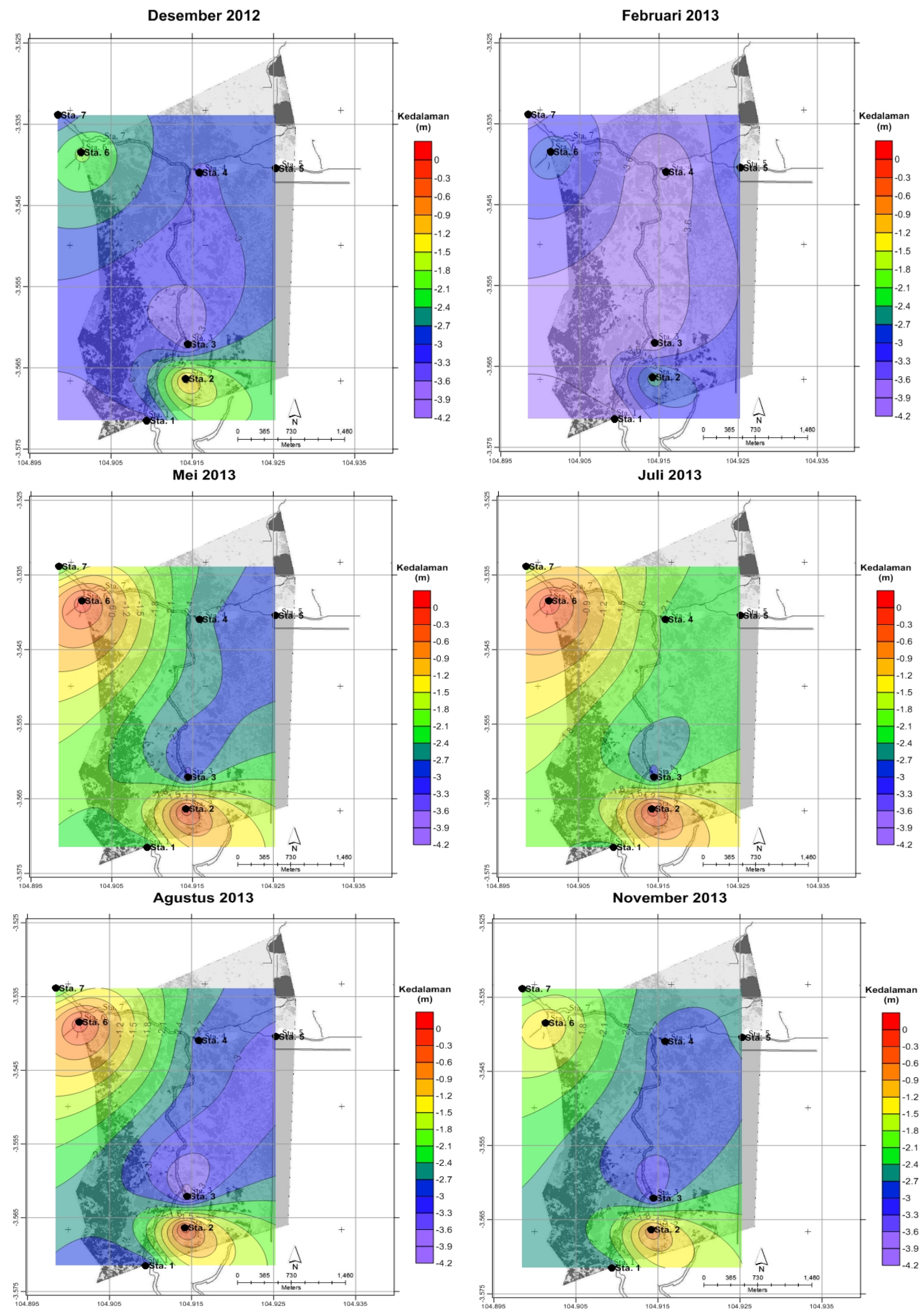

Gambar 3. Profil kedalaman air di area RBLL dari Bulan Desember 2012, Februari 2013, Mei 2013, Juli 2013, Agustus 2013 dan November 2013 (Garis antar warna dalam peta menunjukkan area dengan kedalaman yang sama atau isodepth). 

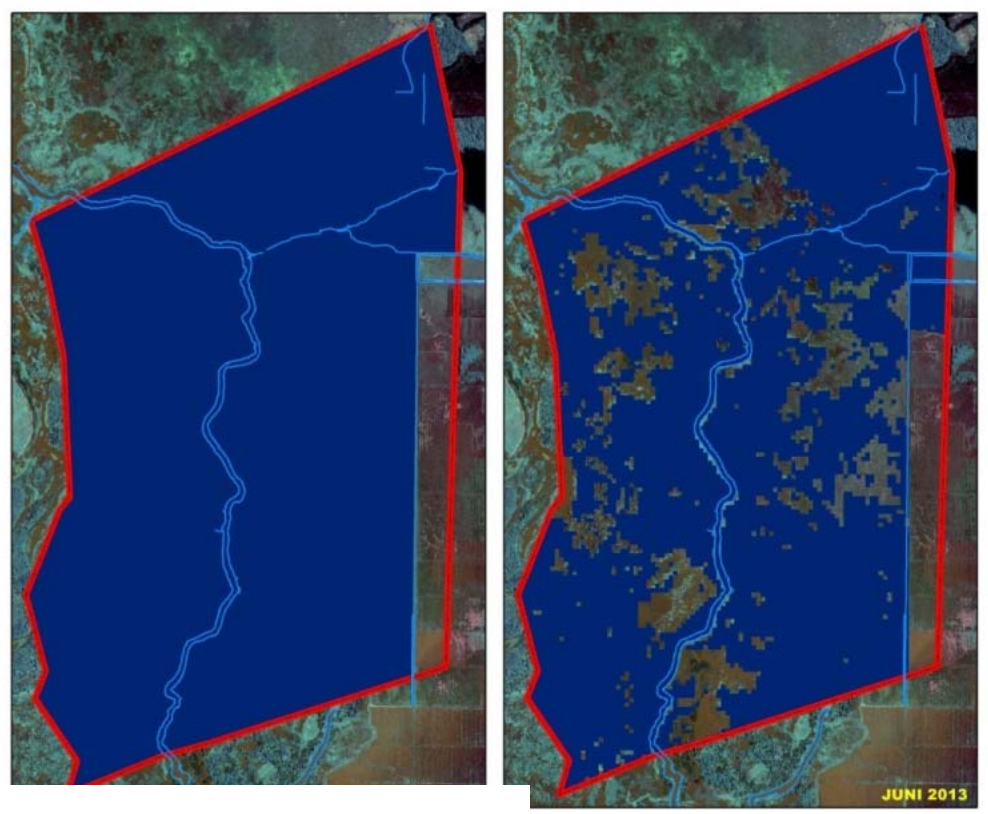

Sumber peta :

1. Peta digital Rupa Bumi Indonesia, Skala 1:50.000, 2010

2. Citra satelit Worldview-2, 2013

3. Hasil digitasi onscreen, 2013

4. Pengamatan dan pengukuran lapangan

Gambar 4. Perbedaan luas area tergenang pada bulan Februari 2013 (1.073,6 ha) dan Juni 2013 (886,1 ha).

Tabel 2. Statistik deskriptif data parameter kualitas air pada masing-masing klaster.

\begin{tabular}{|c|c|c|c|c|c|c|c|}
\hline \multirow{2}{*}{\multicolumn{2}{|c|}{ Parameter }} & \multicolumn{5}{|c|}{ Periode penggenangan } & \multirow{2}{*}{$\begin{array}{c}\text { Rataan } \pm \text { STD } \\
\text { selama setahun }\end{array}$} \\
\hline & & $\frac{\mathrm{I}}{\text { Rerata } \pm \text { STD }}$ & $\begin{array}{l}\text { II } \\
\text { Nilai }\end{array}$ & \multirow{2}{*}{$\begin{array}{c}\frac{\text { III }}{\text { Nilai }} \\
2,76\end{array}$} & \multirow{2}{*}{$\frac{\text { IV }}{\frac{\text { Rerata } \pm \text { STD }}{2,33 \pm 0,34}}$} & \multirow{2}{*}{$\begin{array}{r}\frac{\mathrm{V}}{\text { Rerata } \pm \text { STD }} \\
2,14 \pm 0,03\end{array}$} & \\
\hline & & $277+022$ & 212 & & & & \\
\hline Kecepatan arus & $\mathrm{m} / \mathrm{det}$ & $0,16 \pm 0,03$ & 0,17 & 0,19 & $0,15 \pm 0,05$ & $0,17 \pm 0,10$ & $0,16 \pm 0,05$ \\
\hline Kecerahan & $\mathrm{m}$ & $0,52 \pm 0,11$ & 0,92 & 0,56 & $\mathbf{0 , 3 5} \pm 0,07$ & $0,45 \pm 0,10$ & $0,48 \pm 0,17$ \\
\hline kekeruhan & NTU & $19,67 \pm 6,56$ & 9,46 & 23,11 & $22,94 \pm 12,28$ & $\mathbf{2 9 , 8 4} \pm 1,56$ & $22,74 \pm 9,04$ \\
\hline Temperatur & ${ }^{\circ} \mathrm{C}$ & $29,4 \pm 0,98$ & 29,4 & 29,7 & $29,2 \pm 0,91$ & $\mathbf{3 0 , 6} \pm 0,35$ & $29,67 \pm 0,88$ \\
\hline $\mathrm{pH}$ & Unit & $\mathbf{5 , 6} \pm 0,24$ & 5,2 & 5,1 & $5,2 \pm 0,31$ & $4,7 \pm 0,30$ & $5,14 \pm 0,41$ \\
\hline DO & $\mathrm{mg} / \mathrm{L}$ & $3,82 \pm 1,50$ & 2,14 & 5,81 & $2,70 \pm 0,84$ & $\mathbf{1 , 3 0} \pm 0,20$ & $2,84 \pm 1,54$ \\
\hline DHL & $\mathrm{mg} / \mathrm{L}$ & $37 \pm 7,14$ & 29 & 29 & $55 \pm 9,50$ & $\mathbf{4 3} \pm 2,18$ & $43,13 \pm 11,50$ \\
\hline BOD & $\mathrm{mg} / \mathrm{L}$ & $2,41 \pm 2,38$ & 1,18 & 5,51 & $1,44 \pm 0,25$ & $\mathbf{0 , 5 5} \pm 0,22$ & $1,78 \pm 1,71$ \\
\hline COD & $\mathrm{mg} / \mathrm{L}$ & $66,19 \pm 0,79$ & 58,23 & 16,84 & $\mathbf{8 0 , 1 6} \pm 0,08$ & $26,06 \pm 0,14$ & $56,04 \pm 44,54$ \\
\hline $\mathrm{N}$ total & $\mathrm{mg} / \mathrm{L}$ & $45,89 \pm 35,42$ & 45,62 & 44,02 & $\mathbf{4 1 , 0 2} \pm 59,91$ & $\mathbf{6 0 , 8 3} \pm 28,92$ & $47,82 \pm 10,30$ \\
\hline Nitrit & $\mathrm{mg} / \mathrm{L}$ & $\mathbf{0 , 4 9} \pm 7,80$ & 0,01 & 0,02 & $0,10 \pm 10,26$ & $0,10 \pm 1,60$ & $0,18 \pm 0,39$ \\
\hline Nitrat & $\mathrm{mg} / \mathrm{L}$ & $0,74 \pm 1,57$ & 2,87 & 3,86 & $\mathbf{5 , 2 8} \pm 0,88$ & $2,02 \pm 0,40$ & $3,01 \pm 2,60$ \\
\hline P total & $\mathrm{mg} / \mathrm{L}$ & $\mathbf{5 , 0 9} \pm 0,08$ & 4,69 & 3,62 & $3,38 \pm 0,05$ & $\mathbf{1 , 8 9} \pm 0,12$ & $3,56 \pm 1,49$ \\
\hline Ortofosfat & $\mathrm{mg} / \mathrm{L}$ & $0,10 \pm 0,41$ & 0,02 & 0,02 & $0,10 \pm 3,08$ & $\mathbf{0 , 1 6} \pm 1,74$ & $0,10 \pm 0,08$ \\
\hline Alkalinitas & $\mathrm{mg} / \mathrm{L}$ & $21 \pm 9,28$ & 23 & 24 & $53 \pm 13,13$ & $27,43 \pm 10,86$ & $33,94 \pm 17,35$ \\
\hline
\end{tabular}

STD : simpangan baku

Periode penggenangan : I (periode tergenang 1, yaitu Bulan Desember 2012, Januari 2013 dan Maret 2013), II (muka air tertinggi, yaitu Bulan Februari 2013), III (mulai surut, yaitu Bulan April 2013), IV (periode surut, yaitu Bulan Mei 2013 sampai dengan Agustus 2013), V (periode tergenang 2 yaitu Bulan September 2013 sampai dengan November 2012).

Pada periode muka air tertinggi (II) dan mulai surut (III) hanya terdapat satu data hasil pengukuran

Nilai yang dicetak tebal tegak merupakan nilai tertinggi, sedangkan nilai yang dicetak tebal dan miring merupakan nilai terendah

pengamatan adalah kekeruhan tinggi, $\mathrm{pH}$ asam, konsentrasi oksigen rendah, dan kaya akan nutrien terutama fosfor dan nitrogen. Karakteristik ini juga ditunjukkan pada rawa banjiran yang telah dimanfaatkan untuk pertanian secara intensif (Shields dkk., 2011).
Berdasarkan hasil pengamatan (Tabel 2), nampak bahwa area RBLL memiliki kekeruhan yang tinggi dan kecerahan yang rendah. Kecerahan tertinggi $(0,92 \mathrm{~m})$ dan kekeruhan terendah $(9,46$ NTU) terjadi pada saat muka air tertinggi. Rataan nilai kecerahan yang diperoleh sebesar $0,35-0,92$ $\mathrm{m}$ dengan rataan tahunan sebesar $0.48 \mathrm{~m}$. 
Kekeruhan relatif lebih rendah pada musim tergenang dan pasang tertinggi, namun relatif lebih tinggi pada saat mulai surut, surut dan mulai pasang. Menurut Alc^antara dkk. (2010), ketika muka air naik atau surut, pertukaran air antara bagian sungai dan rawa menjadi faktor utama yang mempengaruhi kekeruhan di area rawa banjiran. Pada saat muka air tinggi, kekeruhan lebih banyak dipengaruhi oleh adanya resuspensi sedimen. Meskipun demikian, pada umumnya area rawa banjiran dikenal dengan karakteristik kekeruhan yang tinggi dan kecerahan yang rendah.

Nilai $\mathrm{pH}$ yang diperoleh 4,7 - 5,6 dengan rataan tahunan sebesar 5,14 menunjukkan kondisi yang cenderung asam. Nilai tertinggi yang diperoleh lebih rendah daripada hasil pengukuran pH di RBLL sejak tahun 1989 sampai dengan tahun 2003 yang sebesar 4,5-6,5 (Utomo dkk., 2008). Menurut Welcomme (1979), bersumber dari kompilasi berbagai studi menunjukkan $\mathrm{pH}$ rawa banjiran berkisar antara 3,6-6,5. Dengan demikian, secara umum perairan rawa banjiran bersifat agak asam sampai netral (nilai $\mathrm{pH} 4$ sampai netral) dengan tendensi lebih asam pada musim kemarau. Pada penelitian ini, nilai $\mathrm{pH}$ terendah terjadi pada awal penggenangan setelah periode surut. Hal ini menurut Welcomme (1979), terjadi penurunan $\mathrm{pH}$ ketika air asam mengalami pencucian oleh hujan maupun air banjir dengan kapasitas penyangga yang kecil di awal musim banjir.

Kandungan oksigen terlarut (Dissolved Oxygen, DO) yang diperoleh yaitu berkisar 1,30$5,81 \mathrm{mg} / \mathrm{L}$. Nilai ini lebih rendah dari nilai rataan DO di RBLL pada tahun 1989 sampai tahun 2003 berkisar 1,5-6,7 mg/L (Utomo dkk., 2008). Hal ini menunjukkan kondisi DO di perairan rawa banjiran cenderung rendah.

Nilai rataan BOD dan COD yang diperoleh yaitu sebesar 1,78 dan 56,04 mg/L. Nilai BOD yang diperoleh ini masih berada di bawah baku mutu berdasarkan Peraturan Pemerintah No. 82 tahun 2001, untuk peruntukan perikanan (kelas C) yaitu sebesar $6 \mathrm{mg} / \mathrm{L}$ sedangkan nilai COD sudah melebihi baku mutu yaitu sebesar $50 \mathrm{mg} / \mathrm{L}$. BOD dan COD yang tinggi mengindikasikan pencemaran bahan organik di perairan. Hasil penelitian Saraswati dkk. (2014), menunjukkan peningkatan COD terutama dipengaruhi oleh masukan bahan pencemar sebagai akibat adanya perubahan tata guna lahan alami menjadi lahan pemukiman maupun industri.

Kandungan nutrien yang diperoleh pada penelitian ini menunjukkan nilai nitrat dan nitrit yang relatif rendah dibandingkan nilai total nitrogen, dan demikian juga nilai orthofosfat yang lebih rendah dibandingkan dengan total P. Hal ini dijelaskan oleh Welcomme (1979), rawa banjiran memiliki karakteristik jumlah partikel inorganik yang besar dan konsentrasi nutrien terlarut biasanya rendah. Rataan nilai total $\mathrm{N}(47,82 \mathrm{mg} / \mathrm{L})$ dan total P (3,56 mg/L) yang diperoleh pada penelitian ini lebih tinggi dibandingkan hasil penelitian Shields dkk. (2011) pada rawa banjiran yang secara intensif dikelola untuk pertanian, yaitu hanya diperoleh total fosfor $0,29 \mathrm{mg} / \mathrm{L}$ dan total nitrogen $1,56 \mathrm{mg} / \mathrm{L}$. Menurut Junk dkk. (1989), pada sistem perairan rawa banjiran menerima nutrien (baik organik maupun inorganik, dalam bentuk gas, terlarut maupun partikulat) secara langsung dari sungai utama, namun juga dipengaruhi oleh faktor-faktor lain, yaitu hujan, runoff, air tanah, dari anak-anak sungai di sekitar rawa banjiran.

Kondisi fluktuasi muka air yang tidak signifikan sepanjang tahun selama waktu penelitian menyebabkan kualitas air antar habitat dan antar periode penggenangan juga hampir sama. Hal ini terlihat dari hasil analisis status baku mutu air di keseluruhan lokasi menunjukkan status yang sama, yaitu tercemar ringan sampai dengan ringan-sedang dengan menggunakan indeks pencemaran, dan dalam status tercemar sedang sampai berat dengan menggunakan analisis STORET (Jubaedah dkk. $2014^{\mathrm{b}}$ ). Demikian juga kondisi tingkat kesuburan perairan dengan menggunakan parameter kecerahan, total fosfor dan klorofil-a menunjukkan tingkat kesuburan yang sangat tinggi (hypereutrophic) di seluruh stasiun pengamatan pada masing-masing periode penggenangan (Jubaedah dkk., 2014 ${ }^{\mathrm{a}}$ ).

Karakteristik kualitas air di RBLL, selain dipengaruhi oleh perubahan fluktuasi muka air, juga dipengaruhi oleh adanya masukan antropogenik. Penggunaan pestisida terutama golongan herbisida di area perkebunan kelapa sawit yang berada di dalam dan sekitar kawasan RBLL merupakan bahan masukan antropogenik yang potensial mempengaruhi kualitas air RBLL. Untuk diketahu bahwa jenis herbisida yang paling banyak digunakan di perkebunan kelapa sawit adalah paraquat dan glyfosat (Anonim, 2005). Hasil analisis terhadap kandungan pestisida terutama jenis herbisida glyfosat dan paraquat ditemukan pada sampel air di seluruh area pengamatan (Gambar 5).

Berdasarkan Gambar 5 terlihat bahwa konsentrasi tertinggi herbisida baik jenis paraquat maupun glyfosat ditemukan di stasiun lebung proyek (stasiun 4). Hal ini disebabkan, lebung proyek merupakan lebung buatan yang terletak berdekatan dengan kanal utama perkebunan kelapa sawit. Lebung ini mendapat limpasan dari kanal pada saat musim banjir atau tergenang, namun area ini tertutup atau tidak memiliki konektivitas dengan sungai utama pada saat musim kering. Dengan 


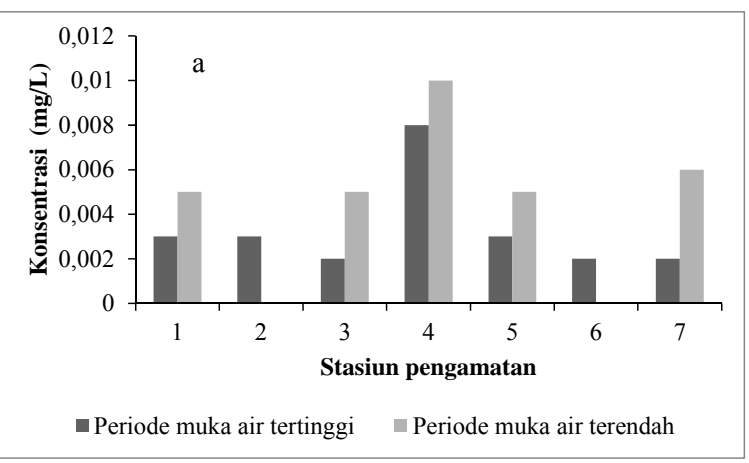

(a)

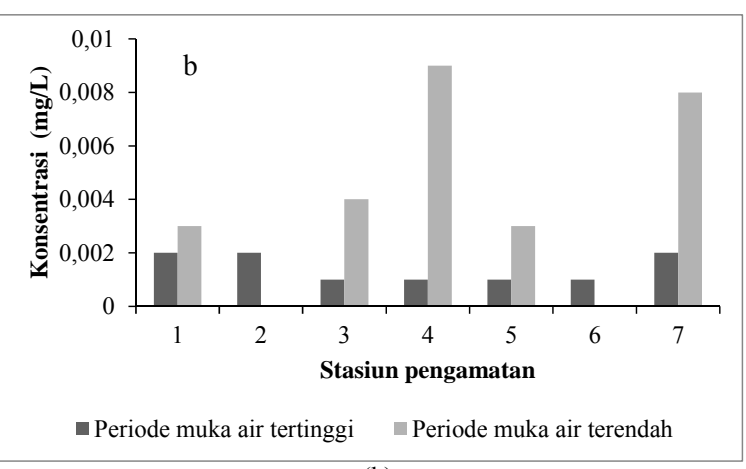

(b)

Gambar 5. Konsentrasi herbisida (a) paraquat dan (b) glyfosat pada masing-masing stasiun (1 : Kapak Hulu, 2: Lebak Kumpai 1, 3 : Suak Buayo, 4: Lebung Proyek, 5 : kanal perkebunan kelapa sawit, 6 : Lebak Kumpai 2, 7 : segmen sungai bagian hilir area RBLL) pada dua periode muka air (tertinggi dan terendah).

Tabel 3. Nilai baku mutu paraquat dan glyfosat

\begin{tabular}{|c|c|c|c|c|}
\hline \multirow{2}{*}{$\begin{array}{l}\text { Peruntukan } \\
\text { baku mutu }\end{array}$} & \multicolumn{2}{|c|}{ Nilai baku mutu } & \multirow[t]{2}{*}{ Pedoman baku mutu } & \multirow[t]{2}{*}{ Referensi } \\
\hline & $\begin{array}{c}\text { Paraquat } \\
(\mu \mathrm{g} / \mathrm{L})\end{array}$ & $\begin{array}{c}\text { Glyfosat } \\
(\mu \mathrm{g} / \mathrm{L})\end{array}$ & & \\
\hline Air minum & 40 & 200 & $\begin{array}{l}\text { The Australian and New Zealand } \\
\text { Environment \& Conservation } \\
\text { Council (ANZECC) }\end{array}$ & Bowmer dkk. (1998) \\
\hline Air minum & 10 & 280 & $\begin{array}{l}\text { Guidelines for Canadian } \\
\text { Drinking Water Quality }\end{array}$ & $\begin{array}{l}\text { Health Canada } 2008 \text { dalam Water } \\
\text { Science and Technology Directorate } \\
\text { Environment Canada (Anonim, 2011) }\end{array}$ \\
\hline $\begin{array}{l}\text { Perlindungan } \\
\text { ekosistem air } \\
\text { tawar }\end{array}$ & & 65 & $\begin{array}{l}\text { NSW EPA (The New South } \\
\text { Wales Environmental Protection } \\
\text { Agencies) }\end{array}$ & Bowmer dkk. (1998) \\
\hline
\end{tabular}

tawar

Tabel 4. Nilai $\mathrm{LC}_{50} 96$ dari paraquat dan glyfosat terhadap beberapa jenis ikan

\begin{tabular}{|c|c|c|c|c|}
\hline & Jenis herbisida & Jenis ikan & $\begin{array}{l}\mathrm{LC}_{50} 96 \\
(\mathrm{mg} / \mathrm{L})\end{array}$ & Referensi \\
\hline \multirow[t]{4}{*}{ Paraquat } & Paraquat dichloride & Clarias gariepinus & 1,75 & $\begin{array}{l}\text { Ladipo dan Doherty } \\
\text { (2011) }\end{array}$ \\
\hline & Paraquat & Oreochromis niloticus & 12,25 & $\begin{array}{l}\text { Babatunde dan Oladimeji } \\
\text { (2014) }\end{array}$ \\
\hline & Paraquat (purity $30 \%$ ) & Trichogaster trichopterus & 1,41 & Banaee $d k k .(2013)$ \\
\hline & Paraquat & Cyprinus carpio L. & 15,11 & Ma dkk. (2014) \\
\hline \multirow[t]{4}{*}{ Glyfosat } & Dizensate glyfosat & Clarias gariepinus & 18,07 & Akinsorotan $d k k$. (2014) \\
\hline & Glyfosat & Oreochromis sp & 3,50 & $\mathrm{Hu}(2010)$ \\
\hline & Glyfosat Roundup & Channa punctatus (Bloch) & 32,54 & Nwani $d k k .(2010)$ \\
\hline & Glyfosat (Forceup) & Tilapia zillii stadia juvenil & 211,80 & Nwani $d k k .(2013)$ \\
\hline
\end{tabular}

Tabel 5. Resiko ekobiologi (Risk Quotient, RQ) hebisida paraquat pada beberapa jenis ikan

\begin{tabular}{|c|c|c|c|}
\hline \multirow[t]{2}{*}{ Jenis herbisida } & \multirow[t]{2}{*}{ Jenis ikan } & \multicolumn{2}{|c|}{ RQ (rerata \pm simpangan baku) } \\
\hline & & Muka air tertinggi (Februari 2013) & Muka air terendah (Juli 2013) \\
\hline \multirow[t]{4}{*}{ Paraquat } & Clarias gariepinus & $0,0019 \pm 0,0012$ & $0,0036 \pm 0,0012$ \\
\hline & Oreochromis niloticus & $0,0003 \pm 0,0002$ & $0,0005 \pm 0,0002$ \\
\hline & Tricogaster tricopterus & $0,0023 \pm 0,0015$ & $0,0044 \pm 0,0016$ \\
\hline & Common carp & $0,0002 \pm 0,0001$ & $0,0004 \pm 0,0002$ \\
\hline \multirow[t]{4}{*}{ Glyfosat } & Clarias gariepinus & $0,0049 \pm 0,0018$ & $0,0183 \pm 0,0097$ \\
\hline & Oreochromis sp & $0,0004 \pm 0,0002$ & $0,0016 \pm 0,0008$ \\
\hline & Tilapia zillii & $0,000007 \pm 0,000003$ & $0,00003 \pm 0,00001$ \\
\hline & Channa punctatus Bloch & $0,000044 \pm 0,000016$ & $0,00017 \pm 0,00009$ \\
\hline
\end{tabular}

Nilai $\mathrm{LC}_{50} 96$ paraquat dan glyfosat masing-masing ikan berdasarkan referensi pada Tabel 4 .

Angka yang dicetak tebal menunjukkan kategori resiko ekobiologi sedang $(0,01<\mathrm{RQ} \leq 0,1)$

demikian, diduga herbisida terkonsentrasi di area ini. Deposit bahan-bahan tersebut di bagian lebung menyebabkan adanya akumulasi yang berakibat peningkatan tingkat kontaminasi di area ini. 
Kanal perkebunan yang diduga merupakan sumber utama dari kedua jenis herbisida ini, memiliki konsentrasi yang tidak terlalu besar. Hal ini diduga karena air kanal bersifat mengalir dengan arus air 0,49 $\mathrm{m} /$ detik pada periode muka air tertinggi (bulan Februari 2013) dan 0,12 m/detik pada periode muka air terendah (bulan Juli 2013). Aliran air ini yang menyebabkan herbisida tidak terkonsentrasi dan diduga juga cenderung menyebabkan tingginya konsentrasi kedua jenis herbisida ini terutama dari golongan glyfosat di stasiun sungai bagian hilir area RBLL atau stasiun 7. Menurut Smalling dkk. (2007), input pestisida terlarut ke badan air di rawa banjiran tergantung pada beberapa faktor, antara lain waktu aplikasi penggunaan pestisida, jumlah pestisida yang digunakan, curah hujan dan arus air.

Berdasarkan Gambar 5 terlihat bahwa konsentrasi paraquat dan glyfosat pada periode muka air terendah (surut) cenderung lebih besar dibandingkan pada periode muka air tertinggi. Hal ini menunjukkan bahwa konsentrasi herbisida lebih banyak dipengaruhi oleh volume air. Peningkatan volume pada saat musim banjir menyebabkan terjadinya proses pengenceran sehingga konsentrasi herbisida menjadi menurun.

Konsentrasi pestisida paraquat dan glyfosat yang diperoleh termasuk rendah apabila dibandingkan dengan beberapa pedoman baku mutu kedua jenis pestisida ini di perairan (Tabel 3). Selain dari baku mutu tersebut, Eisler (1990) menetapkan konsentrasi paraquat kurang dari 500 $\mu \mathrm{g} / \mathrm{L}$ untuk ikan jenis carp. Herbisida paraquat merupakan herbisida yang bersifat toksik terhadap ikan (Akinsorotan, 2014). Pada Tabel 4 disajikan beberapa nilai $\mathrm{LC}_{50} 96$ dari paraquat dan glyfosat terhadap beberapa jenis ikan.

Berdasarkan konsentrasi kedua jenis herbisida pada masing-masing stasiun pengamatan serta nilai $\mathrm{LC}_{50} 96$ jam dari beberapa jenis ikan, diperoleh nilai resiko ekobiologis dari kedua jenis herbisida tersebut (Tabel 5). Dari Tabel 5 tersebut terlihat bahwa resiko bioekologis kedua jenis herbisida terhadap ikan tergolong masih rendah $(<0,01)$ kecuali resiko ekobiologis glyfosat terhadap Clarias gariepinus stadia juvenil pada periode muka air terendah yang tergolong sedang $(0,01<\mathrm{RQ} \leq 0,1)$.

Menurut Palma dkk. (2004), nilai RQ $<1$ menunjukkan tidak ada efek samping yang terjadi disebabkan ekspose jenis herbisida tersebut ke dalam perairan. Meskipun demikian perlu diwaspadai efek additif atau sinergisme antar berbagai jenis herbisida yang dapat menyebabkan resiko ekobiologis yang lebih besar pada ikan dan organisme perairan lainnya yang berada di area RBLL maupun rawa banjiran di sekitarnya.

\section{KESIMPULAN}

Kualitas air RBLL selama setahun pengamatan menunjukkan karakteristik yang hampir sama, yaitu $\mathrm{pH}$ cenderung asam, keruh, kandungan oksigen rendah dan konsentrasi total nitrogen dan total fosfor yang tinggi. Perairan RBLL juga terindikasi mengandung herbisida jenis paraquat dan glyfosat dengan konsentrasi rendah, sehingga resiko ekobiologi yang ditimbulkan dari kedua jenis herbisida ini masih tergolong rendah sampai sedang.

\section{UCAPAN TERIMAKASIH}

Penelitian ini didanai oleh BPPS DIKTI 2011 (No. 1285/E/T/2011) dan Hibah Disertasi Doktor 2014 (No. 212/UN9.3.1/LT/2014)

\section{DAFTAR PUSTAKA}

Akinsorotan, A.M., 2014. Toxicity of Dizensate (Glyphosate Herbiside) on Clarias gariepinus Fingerlings. Adv. Res. Biol. Sci., 2(1):1-5.

Alc^antara, E., Novo, E., Stech, J., Lorenzzetti, J., Barbosa, C., Assireu, A., dan Souza, A., 2010.

A Contribution to Understanding The Turbidity Behaviour in an Amazon Floodplain. Hydrol. Earth Syst. Sci., 14:351-364.

Anonim, 1998. Standar Methods for The Examination of Water and Wastewater. 18th edition, American Public Health Association (APHA).

Anonim, 2005. Penggunaan Pestisida di Perkebunan Kelapa Sawit. Bulletin Down to Earth 66. Website: http://www.downtoearthindonesia.org/id/story/penggunaan-pestisidadi-perkebunan-kelapa-sawit.

Anonim, 2011. Presence and Levels of Priority Pesticides in Selected Canadian Aquatic Ecosystem. Water Science and Technology Directorate Environment Canada. Minister of The Environment, Canada, pp 1-111.

Asyari, Utomo, A.D., dan Nurdawati, S., 2002. Inventarisasi dan Biologi Reproduksi Beberapa Jenis Ikan pada Berbagai Tipe Suaka Perikanan di Sungai Lempuing Kabupaten Ogan Komering Ilir Sumatera Selatan. Jurnal Ilmu-Ilmu Perairan dan Perikanan Indonesia, 9:43-51.

Babatunde, M.M., dan Oladimeji, A.A., 2014. Comparative Study of Acute Toxicity of Paraquat and Galex to Oreochromis niloticus. 
International Journal of Advanced Scientific and Technical Reserach, 4(3):437-444.

Banaee, M., Davoodi, M.H., dan Zoheiri, F., 2013. Histopathological Changes Induced by Paraquat on Some Tissues of Gourami Fish (Trichogaster trichopterus). Open Veterinary Journal, 3(1):36-42.

Bowmer, K.H., Korth, W., Scott, A., McCorkell, G., dan Thomas, M., 1998. Pesticide Monitoring in The Irrigation Areas of SouthWestern NSW 1990-1995. CSIRO Land and Water. Technical report 17/78. p 156.

Eisler, R., 1990. Paraquat Hazards to Fish, Wildlife, and Invertebrates : A Synoptic Review. Biological Report, 85(1.22):1-38.

Graham, R., dan Harris, J.H., 2005. Floodplain Inundation and Fish Dynamics in The MurrayDarling Basin. Current Concepts and Future Research : A Scoping Study. CRC for Freshwater Ecology, Canberra. pp 1-56.

Hu, W., 2010. Risk Assessment of Three Herbicides Used in Rice Fields in Californian Watersheeds on Freshwater Fishes. Halmstad University, School of Business and Engineering, Applied Environmental Sciences, Halmstad. pp 1-33.

Husnah, 2008. Potential Threat to The Floodplain Ecosystem of Lempuing River, South Sumatera, dalam: Hartoto, D.I., Koeshendrajana S., Kartamihardja E.S., Utomo, A.D., dan Nasution Z. (ed), Fisheries Ecology and Management of Lubuk Lampam Floodplain Musi River, South Sumatera. Research Institute for Inland Water Fisheries, Ministry of Marine and Fisheries Affairs, Palembang, pp149-155.

Jubaedah, D., Kamal, M.M., Muchsin., I., dan Hariyadi, S., 2014a. Trophic State of Floodplain River, Lubuk Lampam South Sumatera Indonesia. (submit ke Makara Journal of Sciences).

Jubaedah, D., Hariyadi, S., Muchsin, I., dan Kamal, M.M., 2014 ${ }^{\mathrm{b}}$. Water Quality Index of Floodplain River Lubuk Lampam, South Sumatera Indonesia. 2014 Singapore Conferences Proceeding International Conference on Environmental and Agriculture Engineering (ICEAE 2014), Singapura, 6-7 Agustus 2014.

Junk, W.J., Bayley, P.B., dan Sparks, R.E.. 1989. The Food-Pulse Concept in The River Floodplain Systems, dalam D.P. Dodge (Ed) Proceeding of the International Large River Symposium. Can. Spec. Publ. Fish Aquat. Sci., 106:110-127.

Karimi, F, Mattae, F, dan Farshchi, P., 2012.
Ecological Risk Assesment of Agricultural Pesticides Throughout The Shadegan Wetland, Iran. Journal of Agricultural Sciences, 4(5):109-116.

Karras, G., Barelos, D.C., Karra, A., Patakioutasi, G., Gigas, G., dan Albanis, T., 2007. Occurrence of Pesticide Persistent in Amvrakikos Gulf-N.W. Greece. The 10th International Conference on Environmental Science and Technology, Kos Island, Greece, 5-7 September 2007.

Ladipo, M.K., dan Doherty, V.F., 2011. Acute Toxicity, Behavioural Changes and Histopathological Effect of Paraquat Dichloride on Tissues of Catfish (Clarias gariepinus). International Journal of Biology, $3(2): 67-74$

Ma, J., Li, X., Li, Y., dan Nu, D., 2014. Toxic Effects of Paraquat on Cytokine Expression in Common Carp, Cyprinus carpio L. Biochem. Mol. Toxicol., 28(11):501-509.

Nwani, C.D., Nagpure, N. S., Kumar, R., Kushwaha, B., Kumar, P., dan Lakra, W.S., 2010. Lethal Concentration and Toxicity Stress of Carbosulfan, Glyphosate and Atrazine to Freshwater Air Breathing Fish Channa punctatus (Bloch). Int. Aquat. Res., 2:105-111.

Nwani, C.D., Ibiam, U.A., Ibiam, O.U., Nworie, O., Onyishi, G., dan Atama, C., 2013. Investigation on Acute Toxicity and Behavioral Changes in Tilapia zillii Due to Glyphosate-Based Herbicide Forceup. J. Anim. Plant Sci., 23(3):888-892.

Palma, G., Sa'nchez-Encina, A., Olave, Y.F., Palma, R., dan Barra, R., 2004. Pesticide Levels in Surface Waters in An AgriculturalForestry Basin in Southern Chile. Chemosphere, 57:763-770.

Saraswati, S.P., Sunyoto, Kironoto, B.A., dan Hadisusanto, S., 2014. Kajian Bentuk dan Sensitivitas Rumus Indeks PI, STORET dan CCME untuk Penentuan Status Mutu Perairan Sungai Tropis di Indonesia. J. Manusia dan Lingkungan, 21(2):129-142.

Shields, F.D., Lizott, Jr.,R.E., dan Knight, S.S., 2011. Spatial and Temporal Water Quality Variability in Aquatic Habitats of a Cultivated Floodplain. River Res. Applic., 29(3):313-329.

Smalling, K.L., Orlando, J.L., dan Kuivila, K.M., 2007. Occurrence of Pesticides in Water, Sediment, and Soil From The Yolo Bypass, California. San Francisco Estuary and Watershed Science, 5(1):1-17.

Utomo, A.D., Kaban, S., dan Hartoto, D.I., 2008. Correlation of Water Level Fluctuation to 
Physico-Chemical Features of Lubuk Lampam floodplain, dalam D.I. Hartoto, Koeshendrajana, S., Kartamihardja, E.S., Utomo, A.D., dan Nasution, Z., (Ed), Fisheries Ecology and Management of Lubuk Lampam Floodplain River, South Sumatera, Research Institute for Inland Water Fisheries, Research Center for Capture Fisheries, Agency of Marine and Fisheries Research, Ministry of
Marine and Fisheries Affairs, Palembang, 2008, pp 8-15.

Welcomme, R.L., 1979. Fisheries Ecology of Floodplain Rivers, Longman Inc., New York, pp 1-317.

$\mathrm{Xu}, \quad$ H., 2006. Modification of Normalized Difference Water Index (NDWI) to Enhance Open Water Features in Remotely Sensed Imagery. International Journal of Remote Sensing, 27(14):3025-3033. 